\title{
Assessing Dispersivity and Expansivity of Clay Soils in the South-East of Yazd with Aim of Investigating Correlation between Them
}

\author{
Nasrin Zare-Junaghani ${ }^{1}$, Hamid Mehrnahad², Mehdi Torabi-Kaveh ${ }^{1 *}$ \\ 1 Department of Geology, Faculty of Science, Yazd University, 89195-741, Yazd, Iran \\ 2 Department of Civil Engineering, Yazd University, 89195-741, Yazd, Iran \\ * Corresponding author, e-mail: m.torabikaveh@yazd.ac.ir
}

Received: 10 February 2019, Accepted: 05 October 2019, Published online: 13 November 2019

\begin{abstract}
Having knowledge about physical, chemical and mechanical properties of problematic soils is necessary when they are applied in construction projects as borrow materials or foundation, because these soils have potential to create large financial losses. This research deals with characterizing dispersive and swelling soils as problematic soils in southeast of Yazd (center of Iran) with aim of establishing a relationship between dispersivity and expansivity indices. In this regard, after performing a series of physical and chemical tests, the characteristics of the soil samples were determined, and their dispersivity degrees were specified by conducting chemical, pinhole and double hydrometer tests. Also, swelling rates of the soils were estimated using direct method (modified free swell index, MFSI) and indirect methods (different criteria developed for swelling assessment). The results showed that chemical parameters overestimate dispersivity of the soil samples (dispersive to semi-dispersive) in compared to pinhole and double hydrometer tests (slightly non-dispersive to moderately dispersive). Different expansivity degrees were defined using the direct and the indirect methods (ignorable to very high) for the soil samples. Among the empirical criteria used to evaluate the swelling potential, the AASHTO's criterion has the closest results to the MFSI in the both boreholes. Also, it revealed that as depth increases, the degree of soil dispersivity and expansivity decrease in response to the reduction of fine grain content in the samples. Finally, the correlations between dispersivity and expansivity indices, showed that sodium absorption ratio (SAR) can be used as a reasonable index to estimate soil swelling potential.
\end{abstract}

\section{Keywords}

problematic soils, dispersivity, expansivity, correlation

\section{Introduction}

Problematic soils, which are formed in different geological conditions, are considered as one of the most challenging issues in geotechnical projects. Hence, field observation and laboratory tests are necessary for identifying such soils. Dispersive and swelling soils are considered as the most common problematic soils. Dispersive soils are defined as clay soils with high sodium percentage, which are highly susceptible to erosion. The tendency of the clays to disperse or de-flocculate depends on the mineralogy and soil chemistry and also on the dissolved salts in the pore water and the eroding water [1]. The previous studies showed that the presence of clay active minerals, such as montmorillonite, low electrolyte concentration, and existence of exchangeable sodium ions, contribute to emerge dispersive behavior. Since identification of dispersive soils is not possible via performing the routine laboratory index tests, many studies have been performed to define methods to identify such soils [2]. In this regards, during past decades, many researchers studied identification methods of dispersivity of soils using chemical or physical properties of soils (e.g. [3-9]). Among the common tests to identify dispersivity of soils are soil dispersion test (in jar), pinhole test, double hydrometer test, and chemical tests [10]. Also during last years, mechanical properties including unconfined compression and compaction tests [3, 11], shear strength test [12], and California Bearing Ratio-CBR [13] were used to identify dispersive soils.

Expansive soils are other common problematic soils which outcrop extensively in the arid and semi-arid regions and greatly affect construction activities in different parts 
of the world [14]. Holtz and Kovacs [15] reported that high plastic clays with a plasticity index greater than $35 \%$ can be considered as expansive soil. Expansive soils show remarkable volumetric changes in result of moisture content changes that it causes swelling and shrinkage behaviors in soil. The pressure caused by this phenomenon leads to damage to civil structures such as light weight buildings, pavements, embankments, and dams [16].

The Free Swell Index (FSI) test, the one dimensional consolidometer test, the load-back test and the constant volume test are the most common direct methods to identify swelling degree of soils [17]. In addition to direct methods, empirical criteria (indirect approaches), which are defined based on physical and index properties of soils, are also applied to express degree of soil expansivity. Due to the importance of the subject of swelling soils, many researchers have studied expansivity of soils using direct and indirect methods (e.g. [18-24]).

In the last decades, holes and ruptures have been occurred on the surface of the Yazd-Ardakan plain (Fig. 1A) which are related to presence of problematic soils in this region. Serious damages such as creation of cracks in buildings and roads, and even forming holes, are visible in this region (Fig. 1B). Presence of dispersive and swelling soils are two possible causes of these phenomena.

Only in a study, Mahmoudi [25] reported presence of swelling soils with moderate expansivity degree around the Ardakan city, where these soils caused cracking in structures of the region. Hence, evaluation of dispersivity and

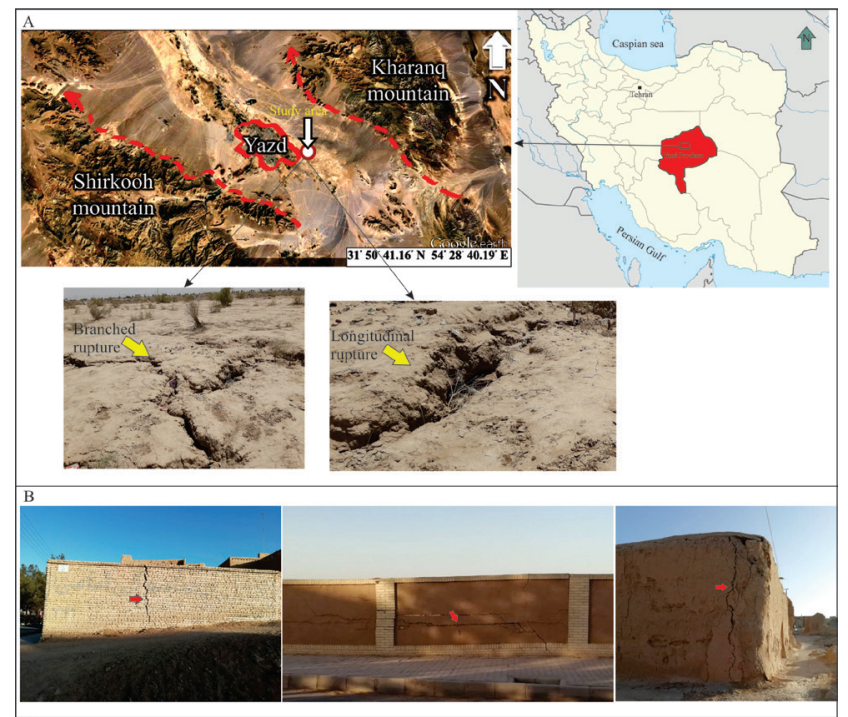

Fig. 1 Geographical situation of the study area along with a view of longitudinal and branched ruptures in the area (A) and cracking in building walls in Yazd-Ardakan plain due to existence of problematic soils (B) swelling of the soils covering Yazd-Ardakan plain is very important. On the other hand, previous studies in relation to dispersive and swelling soils, carried out mainly without regarding the relationship between the characteristics of dispersivity and expancivity of soils. Considering these issues, in this study, representative soil samples, taken from the excavation of two boreholes in the southeast of Yazd-Ardakan plain, will be investigated from dispersivity and expansivity points of view and then the relationships among indices of dispersivity and expansivity will be assessed. For this purpose, after determining the physical (moisture content, gradation, porosity, Atterberg limits, specific gravity, natural density and etc.) and chemical (cation analysis, XRD and XRF) properties, the dispersivity degree of the soil samples will be measured using chemical parameters, pinhole test and double hydrometer test.

Also, the swelling potential of the soil samples will be estimated using direct method (modified free swell index, MFSI) and indirect criteria (different criteria developed for swelling assessment). Finally, based on results and via statistical methods, the relationship between dispersivity and the expansivity will be examined.

\section{Geographical situation, climatology, geomorphology and geology}

Yazd-Ardakan plain is a tectonic depression between Kharanaq and Shirkooh mountains. Kharanaq and Shirkooh mountains with trend of northwest-southeast are located in the east and the west of the study area respectively. This plain includes Ardakan, Meybod, Ashkezar, Mehriz and Yazd cities and its area is about 11775 square kilometers. Between these two mountains, remains of the Tertiary period outcrop in form of low-altitude dunes of conglomerate - sandstones, which have locally changed the topography and created certain geomorphologic conditions. Calcareous formations of Cretaceous form highland areas in the region [26].

Yazd city was developed on recent alluvial deposits (Q) and Aeolian dunes with age of Quaternary. The study area includes clay plains located in the southeast of Yazd (Fig. 1). Longitudinal and branched ruptures are the main geomorphological forms in the region that mechanism of their occurrence is questionable (Fig. 1A).

From climatology point of view, the study area has hot and dry climate (desert or arid climate) with very hot and dry summers, and relatively cold and dry winters. Level of rainfall in Yazd is low, as the average amount of annual rainfall for a period of 66 years is about $55.9 \mathrm{~mm}$ for the 
region. Also the average annual temperature for the same period is about $19{ }^{\circ} \mathrm{C}$. The evaporation rate in Yazd province is very high due to dry weather and high wind speeds, so that the average evaporation from the measuring pan is between 3000 and $3400 \mathrm{~mm}$ in plain areas (altitudes less than $1200 \mathrm{~m}$ ) and it decreases at highlands to the range of $2000 \mathrm{~mm}$ to $2500 \mathrm{~mm}$.

\section{Sampling}

After carrying out preliminary studies and assessing geological condition of the study area, two boreholes with depths of $5 \mathrm{~m}$ (borehole A, along the ruptures) and $6 \mathrm{~m}$ (borehole B in distance of two kilometers from the ruptures) were drilled to obtain samples for laboratory experiments (Fig. 2). Samples were collected in both disturbed and undisturbed forms for every one meters of soil depth.

\section{Materials and methods}

\subsection{Physical and chemical tests}

After obtaining the samples, a variety of physical tests, including moisture content [27], natural density [28], specific density [29], particle size analysis [30] and Atterberg limits [31] were carried out on 11 samples obtained from different depths of the two boreholes. Considering that the degree of dispersivity of soils is largely dependent on their chemical composition, the X-Ray Diffraction (XRD) test was performed on representative samples (5 samples at depths of 2 and 4 meters of the borehole A and 2, 4, 6 meters of the borehole B) by a Philips Analytical X-Ray B.V device, and the radiation angle $(2 \theta)$ of $4.01^{\circ}-59.99^{\circ}$. Also, the quantification of clay minerals is one of the most important subjects in evaluating clay-rich soil, but it is still challenging due to the unique structures and various element compositions of clay minerals [32]. During past decades, XRD has been considered as a reliable analytical approach in quantifying clay minerals. Hence, XRD method was also used to determine the percentage of clay minerals. Spectra of clay minerals from two samples at $4 \mathrm{~m}$ of the two boreholes were used to determine the percentage

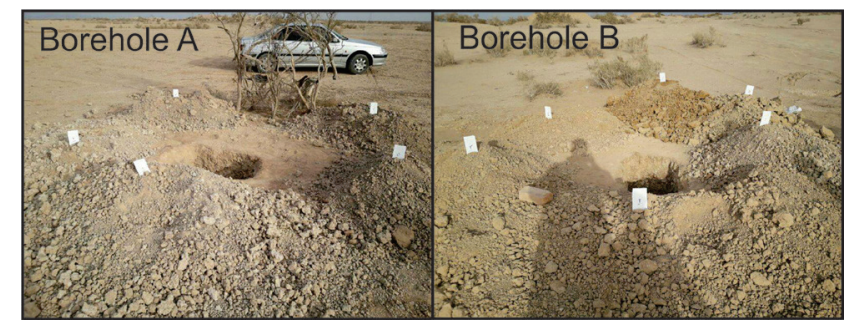

Fig. 2 A view of the boreholes A and B of clay minerals. So that, by calculating the area under the clay peaks in the XRD spectrum, the percentage of clay minerals was obtained.

Chemical analysis is considered as major step of determination of mineral nature, and characterizing different oxides in relation to soil samples is essential [33]. Therefore, the soil samples were subjected to X-Ray Fluorescence (XRF) to analyze the chemical composition of the samples. Two XRF tests were carried out using S4 EXPLORER / X-Ray Spectrometry-Bruker (WD XRF) device to measure the number of main oxides and sub-elements in representative samples from the both boreholes.

\subsection{Experiments for determining soil dispersivity degree}

Various laboratory experiments are commonly used to identify dispersive soils, including the double hydrometer test, the crumb test, pinhole test and various chemical analyses of the soil [34]. In most cases, a combination of the results obtained from the methods is considered for determining dispersivity of soil.

In this study chemical analyses were carried out on 11 samples obtained from both boreholes with aim of determining the amount of sodium in the soil samples. Using the analyses, the exchangeable cations on the clays and the cations in the saturation extract were measured. Then, three chemical parameters including the total dissolved solids (TDS), the sodium absorption ratio (SAR), and the percent of sodium (PS) were calculated according to Eqs. (1)-(3):

$$
\begin{aligned}
& \mathrm{TDS}=\mathrm{Ca}^{2+}+\mathrm{Mg}^{2+}+\mathrm{Na}^{+}+\mathrm{K}^{+}, \\
& \mathrm{PS}=\frac{\mathrm{Na}^{+}}{\mathrm{TDS}} \times 100, \\
& \mathrm{SAR}=\frac{\mathrm{Na}^{+}}{\sqrt{\frac{\mathrm{Ca}^{2+}+\mathrm{Mg}^{2+}}{2}}},
\end{aligned}
$$

where TDS is total dissolved solids (meq/l), $\mathrm{Na}^{+}$is sodium concentration (meq/l), $\mathrm{Ca}^{2+}$ is calcium concentration (meq/l), $\mathrm{Mg}^{2+}$ is magnesium concentration (meq/l), and $\mathrm{K}^{+}$ is potassium concentration (meq/l).

Also, the pinhole test was used to assess dispersivity of the samples. This test is one of the most common physical tests for determination of soil dispersivity. Sherard et al. [35] introduced this test for simulating the action of water draining through a pipe in the soil. The ASTM-D4647 standard [36] was used to perform pinhole 
test on 5 samples obtained from depths of $2 \mathrm{~m}$ and $4 \mathrm{~m}$ of borehole A and depths of $2 \mathrm{~m}, 4 \mathrm{~m}$, and $6 \mathrm{~m}$ of borehole B. According to this standard, as water flows through a small hole punched in the center of a specimen, effluent turbidity and pinhole size at the end of each test are recorded. The specimen is considered as dispersive, when the effluent is highly turbid (murky) and the pinhole is enlarged. The specimen is considered as non-dispersive if the opposite is observed. Classification of soils based on pinhole test results is presented in ASTM-D4647 standard [36].

Another suitable test to identify dispersive soils is the double hydrometer test. In this test, rate of suspension of clay fraction in a soil is measured to express level of dispersivity. Therefore, the double hydrometer test according to ASTM-D4221 standard [37], was performed on 11 samples from different depths of the two boreholes. The procedure suggested by ASTM includes two parallel tests. First, performing the standard hydrometer test which includes determination of percentage of particles with size of less than $0.005 \mathrm{~mm}$ in soil. Second, a similar test to the first test but without use of chemical dispersant. Finally, percentages of $0.005 \mathrm{~mm}$ sized particles in the both tests are used to define the dispersion ratio or dispersivity percentage of soil (Eq. (4)).

The percentage of particles smaller

$\begin{aligned} D P= & \frac{\text { than } 0.005 \mathrm{~mm} \text { in the first test }}{\text { The percentage of particles smaller }} \times 100, \\ & \text { than } 0.005 \mathrm{~mm} \text { in the second test }\end{aligned}$

where $D P$ is dispersivity percentage. Bell and Walker [38] classified soils as highly dispersive, dispersive, moderately dispersive and non-dispersive according to the obtained dispersion ratio.

\subsection{Experiments for determining soil expansivity degree} Measuring soil swelling degree is done as directly or indirectly. Direct methods include numerous laboratory tests such as free swell, zero swell, loaded swell, restricted swell, constant volume, swell-consolidation, and double oedometer tests. In spite of validity of direct measurements, their application is not common, because they are usually time consuming. Recently, Sivapullaiah et al. [39] introduced a new testing method to determine modified free swell index (MFSI), which provides a better estimation of the potential for swelling of clay soils. In the present study, MFSI was used to assess swell potential of 11 samples obtained from different depths of the boreholes. The MFSI is defined as Eq. (5):
$\mathrm{MFSI}=\frac{V-V_{S}}{V_{S}}$,

where $V$ is the soil volume after swelling, $V_{S}$ is volume of the solid fraction of soil particles.

During past decades, many researchers (e.g. [18, 40-44]) tried to develop empirical correlations to predict swelling potential of soils using physical and index properties such as Atterberg limits, percentage of clay content, activity level, initial moisture content and density. In this study, five criteria including Chen [45], modified Van der Merwe [46], Williams [47], Seed et al. [42], and AASHTO [48] were used to indirectly measure the potential for the swelling of the soil samples. The plasticity index (PI) is used in the Chen and modified Van der Merwe criteria as a predictor parameter. Williams's criterion uses plasticity index, clay percentage, and activity number of soil to assess swelling potential. The criterion reported by Seed et al. [42] determines the soil swelling rate using the percentage of clay particles in soil and activity number. The AASHTO's criterion uses the liquid limit and soil plasticity index characteristics to estimate the swelling. All depths of the both boreholes were studied using these criteria.

\section{Results and discussion}

\subsection{Results of the physical and chemical experiments}

As mentioned in Section 4, a series of physical and chemical experiments were done on the obtained samples, and the results are presented in Tables 1-3 and Figs. 3-5. According to the obtained results (Table 1), in borehole $\mathrm{A}$, the plasticity index shows an ascending trend due to increase of water absorption potential in response to increasing depth. The soil samples were classified using plasticity chart [49] and based on their Atterberg limits (Fig. 3). Considering changes in the Atterberg limits, two types of soil layers can be distinguished. So that, with increasing depth, the soil type has changed from clay with low plasticity (CL) to clay with high plasticity $(\mathrm{CH})$ (Fig. 3). In case of borehole B, three layers of soil can be distinguished based on the calculated Atterberg limits. Soil samples collected from depths of 3 and 4 meters of the borehole B show lower Atterberg limits than the samples from other depths of the borehole, and therefore these samples are classified in CL category, where the other samples are considered to be $\mathrm{CH}$.

Considering what was mentioned, it can be said that in both the boreholes, the clay soils have layering, resulted from the change in the Atterberg limits. The percentage 
Table 1 Physical properties of the samples of boreholes A and B

\begin{tabular}{lcccccccccccccc}
\hline Sample & Depth (m) & Activity (A) & $\begin{array}{c}\text { Moisture } \\
\text { content }(\%)\end{array}$ & $\begin{array}{c}\text { Density } \\
\left(\mathrm{gr} / \mathrm{cm}^{3}\right)\end{array}$ & $G_{s}$ & $e_{0}$ & LL & PL & PI & $\begin{array}{c}\text { Fine grain } \\
(\%)\end{array}$ & $\begin{array}{c}\text { Clay } \\
\text { Bilt }\end{array}$ & $\begin{array}{c}\text { Soil } \\
\text { type }\end{array}$ \\
\hline \multirow{3}{*}{ Borehole A } & 1 & 1.264 & 3.00 & 1.60 & 2.80 & 0.75 & 44 & 26.30 & 17.70 & 96.28 & 14 & 82.28 & $\mathrm{CL}$ \\
& 2 & 1.307 & 4.16 & 1.58 & 2.72 & 0.72 & 44.50 & 26.20 & 18.30 & 95.56 & 14 & 81.56 & $\mathrm{CL}$ \\
& 3 & 1.58 & 4.51 & 1.59 & 2.72 & 0.71 & 47.90 & 22 & 25.90 & 94.64 & 14 & 80.64 & $\mathrm{CL}$ \\
& 4 & 2.363 & 5.30 & 1.55 & 2.65 & 0.71 & 51 & 25 & 26 & 90.31 & 11 & 79.31 & $\mathrm{CH}$ \\
& 5 & 3.163 & 6.25 & 1.53 & 2.65 & 0.70 & 54.30 & 19.50 & 34.80 & 89.2 & 11 & 78.2 & $\mathrm{CH}$ \\
& 1 & 1.128 & 9.12 & 1.49 & 2.60 & 0.74 & 50 & 28 & 22 & 98.21 & 19.50 & 78.71 & $\mathrm{CH}$ \\
Borehole B & 2 & 1.756 & 10.00 & 1.52 & 2.72 & 0.78 & 51.90 & 23.80 & 28.10 & 96.07 & 16 & 80.07 & $\mathrm{CH}$ \\
& 3 & 1.54 & 14.95 & 1.54 & 2.60 & 0.68 & 44.60 & 23.07 & 21.53 & 91.73 & 14 & 77.73 & $\mathrm{CL}$ \\
& 4 & 1.8 & 19.90 & 1.57 & 2.72 & 0.42 & 39.20 & 17.64 & 21.56 & 89 & 12 & 77 & $\mathrm{CL}$ \\
& 5 & 3.02 & 15.62 & 1.63 & 2.72 & 0.40 & 52 & 21.80 & 30.20 & 87 & 10 & 77 & $\mathrm{CH}$ \\
& 6 & 3.693 & 11.30 & 1.70 & 2.65 & 0.35 & 59.15 & 22.22 & 36.93 & 85 & 10 & 75 & $\mathrm{CH}$ \\
\hline
\end{tabular}

Table 2 Results obtained from XRD test of clay minerals

\begin{tabular}{lcccc}
\hline Sample & Depth $(\mathrm{m})$ & Smectite $(\%)$ & Illite $(\%)$ & Kaolinite + Chlorite $(\%)$ \\
\hline Borehole A & 4 & 4.45 & 15.45 & 80.08 \\
Borehole B & 4 & 3.57 & 80.35 \\
\hline
\end{tabular}

Table 3 Results of XRF test on the soil samples

\begin{tabular}{lccccccc}
\hline \multirow{2}{*}{ Sample } & Depth $(\mathrm{m})$ & \multicolumn{5}{c}{ Oxide type $(\%)$} \\
& & $\mathrm{Na}_{2} \mathrm{O}$ & $\mathrm{K}_{2} \mathrm{O}$ & $\mathrm{SiO}_{2}$ & $\mathrm{MgO}_{2}$ & $\mathrm{Cao}_{2}$ \\
\hline Borehole A & 2 & 0.67 & 1.45 & 25.9 & 6.04 & 13.3 \\
Borehole B & 2 & 1.2 & 2.26 & 22 & 8.29 & 13.2 \\
\hline
\end{tabular}

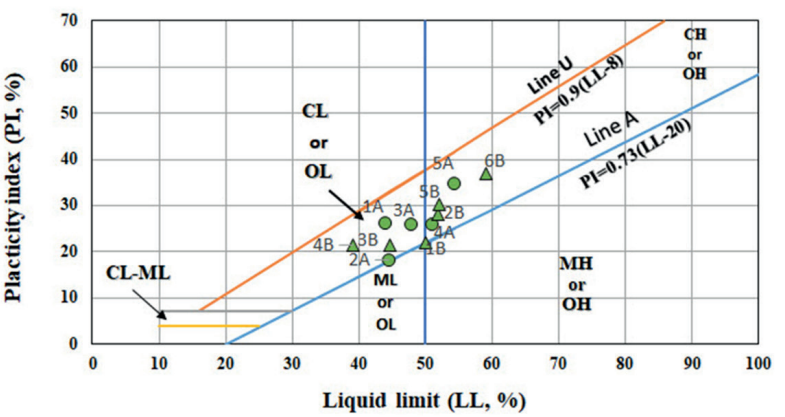

Fig. 3 Classification of the soil samples based on plasticity chart [49]

of moisture content in borehole A has an increasing trend due to an increase in the percentage of fine grains (clay and silt), while a specific trend is not visible in case of borehole $\mathrm{B}$ in relation to increasing depth. It is because of change in content of sand and clay in length of the borehole. The specific gravity for solid particles forming soils can vary from 2.63 to 2.9 [50]. The specific gravity of bright colored sand, often made of quartz, is estimated to be about 2.65. In case of clay minerals depending on clay mineral type, the specific gravity is different. For example, the specific gravity range for kaolinite is 2.61-2.66, for illite is 2.6-2.86 and for montmorillonite is 2.74-2.78 [50]. Therefore, with increasing clay minerals in a soil, its solid part specific gravity will enhance. According to the results (Table 1), the specific gravity $\left(G_{s}\right)$ of the solid for the both boreholes varies from 2.6 to 2.8 , indicating a high percentage of clay and silt in the soil samples. According to the performed XRD analysis (Fig. 4), quartz, calcite, dolomite and clay minerals are the major constituents of the soil samples and plagioclase (albite) is the minor constituent.

As mentioned in Section 4, XRD analysis was also done on clay fraction of the soil samples (Fig. 5). The results showed that the main clay mineral is illite and the other clay minerals are kaolinite, chlorite and smectite. In addition, the interpretation of the XRD patterns showed an increase of 2.8 to 2.9 times the ratio of the intensity of the first peak of illite to the its second peak in the boreholes A and B respectively. This indicates the superiority of the trioctahedral illite (created from biotite decomposition) to the dioctahedral illite (created from muscovite decomposition) in the soil of the region. In fact, the more decomposability characteristics of biotite compared to muscovite has led to a greater release of magnesium and iron elements in the soils containing these minerals. 

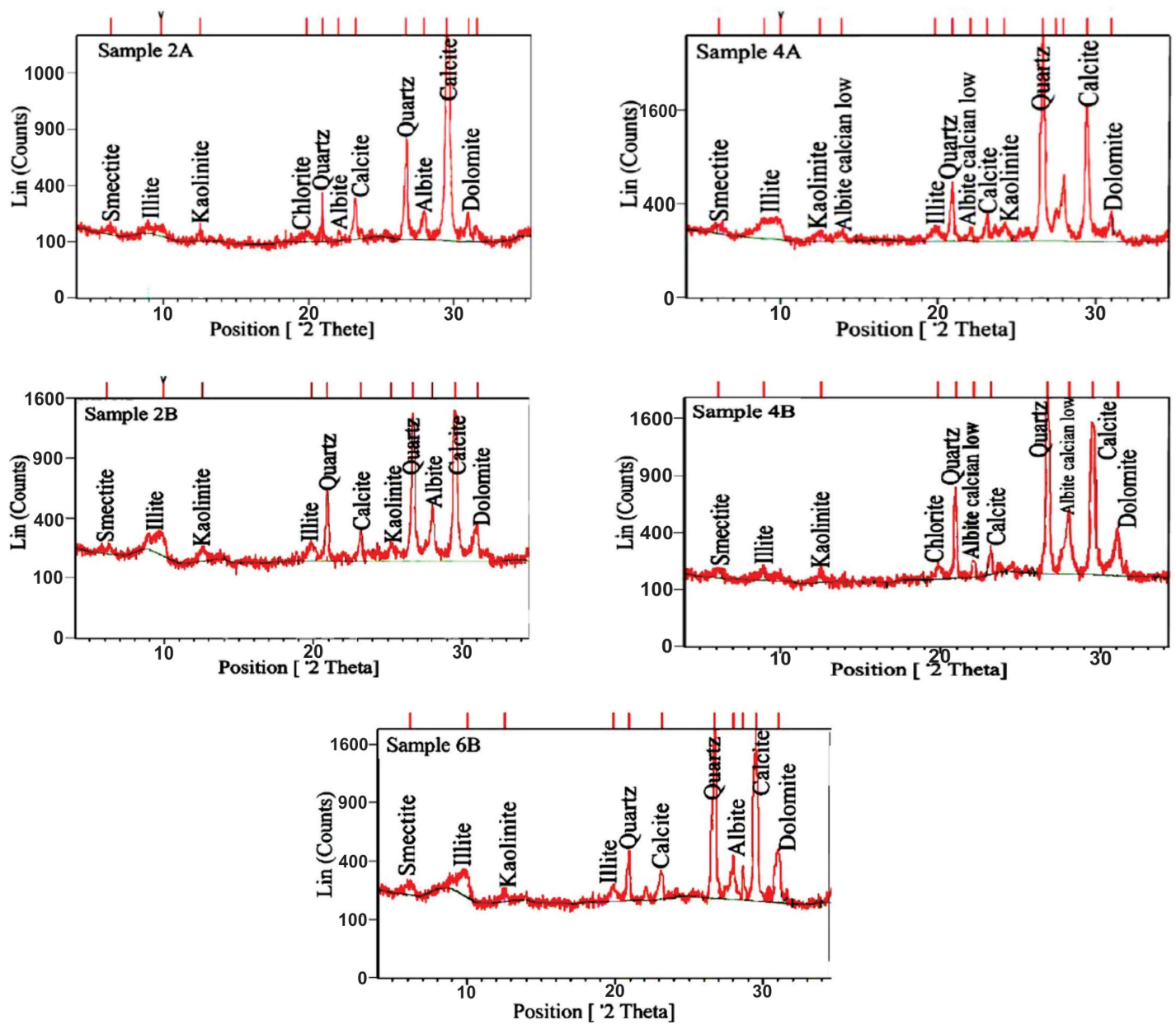

Fig. 4 The XRD chart of soil samples in both boreholes
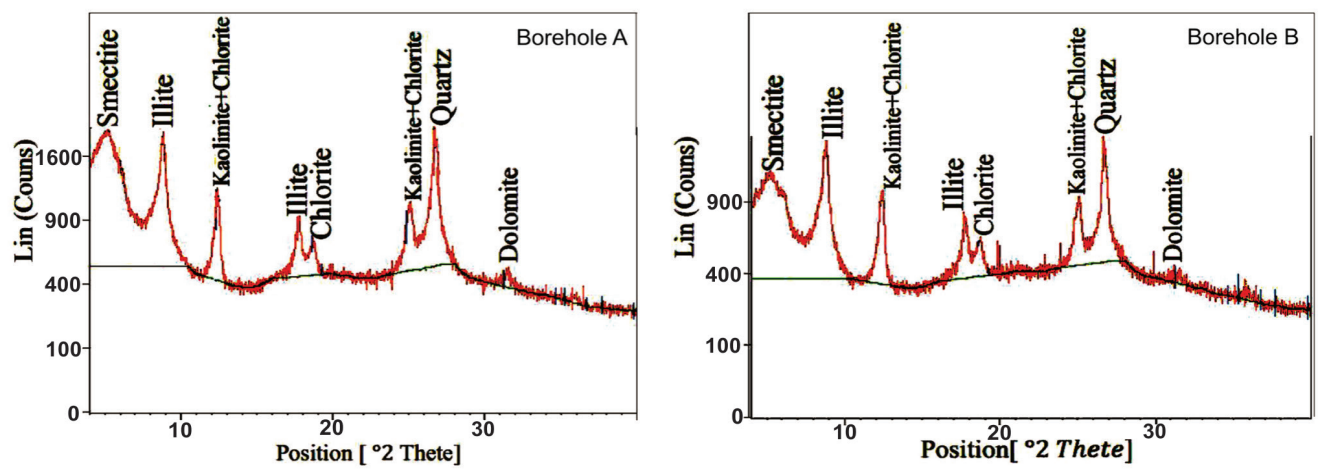

Fig. 5 The XRD chart of clay minerals in both boreholes

Also, calculation of percentages of clay minerals in the soil samples, obtained from depth of $4 \mathrm{~m}$ of the both boreholes, confirmed that illite is the main part of clay minerals in the samples (Table 2).

The results of XRF analyses (Table 3 ) on representative samples of the two boreholes showed that in borehole A, the percentage of $\mathrm{Na} 2 \mathrm{O}$ is less than that for borehole $\mathrm{B}$, but the $\mathrm{CaO}$ percentage is slightly higher. Therefore, it can be expected that the dispersivity potential of the soils of borehole $\mathrm{A}$ is less than borehole $\mathrm{B}$. Also, since the total content of $\mathrm{SiO}_{2}$ and $\mathrm{CaO}$ in the borehole $\mathrm{A}$ is higher than borehole $\mathrm{B}$, it is expected that the soil strength in borehole $\mathrm{A}$ is more than borehole $\mathrm{B}$.

\subsection{Results of soil dispersivity detection tests}

The chemical tests were carried out based on what mentioned in Section 4 and the results are presented in Table 4. As can be seen from Table 4, all the three parameters 
(SAR, TDS and PS) show descending trend with increasing depth. The soil samples were classified (Table 4) based on their PS values according to the classification presented by [38]. The results showed that in borehole A up to $3 \mathrm{~m}$ depth, the soil samples fall in dispersive category, and other samples are considered as intermediate dispersive soils. Also, all the samples of borehole B are intermediate dispersive soils. Based on the data presented in Table 4, the locations of samples on the graph presented by Sherard et al. [51] were found (Fig. 6). The results showed that eight samples fall in the dispersive zone and three samples fall in the middle zone, while none of the samples are located in the non-dispersive zone.

The results of the pinhole tests are presented in Table 5. The results showed that all samples in borehole $\mathrm{A}$, and samples of depths of less than $4 \mathrm{~m}$ in borehole $\mathrm{B}$, fall in ND3 and ND4 categories (moderately to slightly dispersive) and the rest (depths of $5 \mathrm{~m}$ and $6 \mathrm{~m}$ ) fall in the ND1 category (nondispersive). Also, the dispersivity percentages calculated based on the double hydrometric test results are

Table 4 The results of the chemical tests performed on the soil samples

\begin{tabular}{|c|c|c|c|c|c|c|c|c|c|c|}
\hline \multirow{2}{*}{ Sample } & \multirow{2}{*}{$\begin{array}{l}\text { Depth } \\
\text { (m) }\end{array}$} & \multicolumn{4}{|c|}{ Concentration (meq/L) } & \multirow{2}{*}{$\begin{array}{c}\text { TDS } \\
(\mathrm{meq} / \mathrm{L})\end{array}$} & \multirow{2}{*}{$\begin{array}{c}\text { SAR } \\
(\mathrm{meq} / \mathrm{L})\end{array}$} & \multirow{2}{*}{ PS (\%) } & \multirow{2}{*}{$\begin{array}{l}\text { Dispersion class } \\
\text { based on PS \% }\end{array}$} & \multirow{2}{*}{$\begin{array}{l}\text { Dispersion class } \\
\text { based on Sherard's } \\
\text { chart (1976) }\end{array}$} \\
\hline & & $\mathrm{Na}^{+}$ & $\mathrm{Mg}^{2+}$ & $\mathrm{Ca}^{2+}$ & $\mathrm{K}^{+}$ & & & & & \\
\hline \multirow{5}{*}{ Borehole A } & 1 & 40.20 & 4 & 5 & 3.95 & 53.15 & 18.95 & 75.635 & Dispersive & Dispersive \\
\hline & 2 & 36 & 4.6 & 6 & 3.294 & 49.894 & 15.63 & 72.153 & Dispersive & Dispersive \\
\hline & 3 & 35.1 & 4.8 & 6.4 & 3 & 49.3 & 14.85 & 71.197 & Dispersive & Dispersive \\
\hline & 4 & 29.5 & 7 & 8 & 2.794 & 47.294 & 10.774 & 62.637 & $\begin{array}{l}\text { Intermediate } \\
\text { dispersive }\end{array}$ & Dispersive \\
\hline & 5 & 22.3 & 8.8 & 9.5 & 2.5 & 43.1 & 7.3 & 51.740 & $\begin{array}{l}\text { Intermediate } \\
\text { dispersive }\end{array}$ & Semi-dispersive \\
\hline \multirow{6}{*}{ Borehole B } & 1 & 52.85 & 13.5 & 15.2 & 4.7 & 86.25 & 13.95 & 61.133 & $\begin{array}{l}\text { Intermediate } \\
\text { dispersive }\end{array}$ & Dispersive \\
\hline & 2 & 51.2 & 13 & 15 & 4.30 & 83.63 & 13.686 & 61.22 & $\begin{array}{l}\text { Intermediate } \\
\text { dispersive }\end{array}$ & Dispersive \\
\hline & 3 & 24.7 & 5.5 & 7 & 4.15 & 41.35 & 9.9 & 59.734 & $\begin{array}{l}\text { Intermediate } \\
\text { dispersive }\end{array}$ & Dispersive \\
\hline & 4 & 20.2 & 3.9 & 6.8 & 3.964 & 34.864 & 8.733 & 57.939 & $\begin{array}{l}\text { Intermediate } \\
\text { dispersive }\end{array}$ & Semi-dispersive \\
\hline & 5 & 17.75 & 3.5 & 6.3 & 3.15 & 30.7 & 8 & 57.817 & $\begin{array}{l}\text { Intermediate } \\
\text { dispersive }\end{array}$ & Semi-dispersive \\
\hline & 6 & 16.2 & 2.9 & 6.1 & 2.6 & 28.2 & 7.6 & 58.273 & $\begin{array}{l}\text { Intermediate } \\
\text { dispersive }\end{array}$ & Semi-dispersive \\
\hline
\end{tabular}

Table 5 Results of the pinhole tests on the soil samples

\begin{tabular}{|c|c|c|c|c|c|c|c|c|}
\hline \multirow{2}{*}{ Sample } & \multirow{2}{*}{$\begin{array}{l}\text { Depth } \\
(\mathrm{m})\end{array}$} & \multirow{2}{*}{$\begin{array}{l}\text { Head } \\
(\mathrm{mm})\end{array}$} & \multirow{2}{*}{$\begin{array}{l}\text { Test time for } \\
\text { given head (min) }\end{array}$} & \multirow{2}{*}{$\begin{array}{l}\text { Final flow rate trough } \\
\text { specimen }(\mathrm{mL} / \mathrm{s})\end{array}$} & \multicolumn{2}{|c|}{ Cloudiness of flow at end of test } & \multirow{2}{*}{$\begin{array}{l}\text { Hole size after } \\
\text { test }(\mathrm{mm})\end{array}$} & \multirow{2}{*}{$\begin{array}{l}\text { Dispersive } \\
\text { Classification }\end{array}$} \\
\hline & & & & & from side & from top & & \\
\hline \multirow{4}{*}{ Borehole A } & \multirow{2}{*}{2} & 50 & 10 & 1.4 & barely visible & slightly dark & $\leq 1.5$ & ND3 \\
\hline & & 180 & 5 & 1.8 & barely visible & slightly dark & $\leq 1.5$ & ND3 \\
\hline & \multirow{2}{*}{4} & 50 & 10 & 1.5 & barely visible & slightly dark & $\leq 1.5$ & ND3 \\
\hline & & 180 & 5 & 1.7 & barely visible & slightly dark & $\leq 1.5$ & ND3 \\
\hline \multirow{6}{*}{ Borehole B } & \multirow[b]{2}{*}{2} & 50 & 10 & 0.85 & slightly dark & moderately dark & 1.5 & ND4 \\
\hline & & 180 & 5 & 0.9 & $\begin{array}{l}\text { Slightly dark } \\
\text { until the dark }\end{array}$ & $\begin{array}{l}\text { Slightly dark } \\
\text { until the dark }\end{array}$ & 1.5 & ND4 \\
\hline & \multirow[b]{2}{*}{4} & 50 & 10 & 0.8 & A little opaque & A little opaque & 1.5 & ND4 \\
\hline & & 180 & 5 & 0.95 & $\begin{array}{l}\text { Slightly dark } \\
\text { until the dark }\end{array}$ & $\begin{array}{l}\text { Slightly dark } \\
\text { until the dark }\end{array}$ & 1.5 & ND4 \\
\hline & \multirow{2}{*}{6} & 50 & 10 & 2.1 & Transparent & A little white & 1 & ND1 \\
\hline & & 180 & 5 & 2.6 & Transparent & Transparent & 1 & ND1 \\
\hline
\end{tabular}




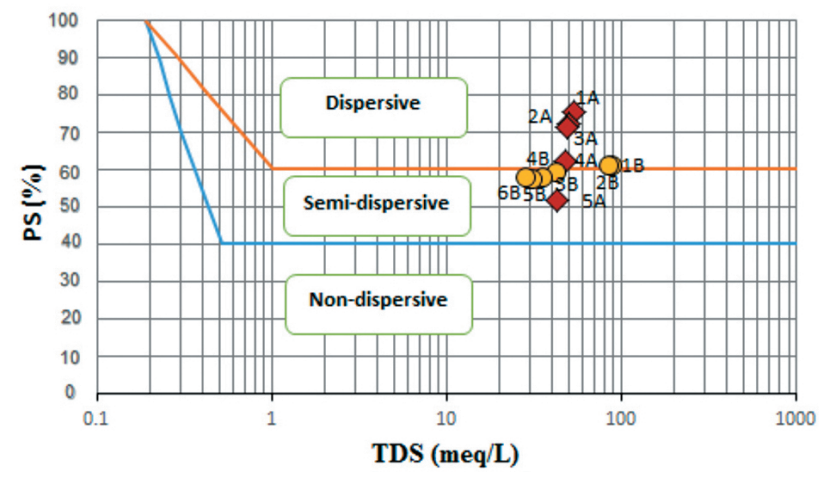

Fig. 6 Dispersivity class of the samples according to Sherard's chart (after Sherard et al. [51])

presented in Table 6. As can be seen from Table 6, except samples of depths of $5 \mathrm{~m}$ and $6 \mathrm{~m}$ from borehole B, which are slightly dispersive and non-dispersive respectively, all the samples are considered as moderately dispersive soils.

\subsection{Results of soil swelling detection tests}

\subsubsection{Direct evaluation of the swelling potential of the soil samples}

Based on the calculated values of MFSI for the soil samples, the potential of swelling of them is expressed in Table 7. As can be seen from Table 7, almost all the samples of borehole A fall in moderate swelling category except sample of depth of $5 \mathrm{~m}$ which is classified as ignorable swelling degree. In case of borehole $\mathrm{B}$, expansivity of half of the borehole depth is moderate and the other half is ignorable.

\subsubsection{Indirect evaluation of the swelling potential of the soil samples}

As it was mentioned in Section 4, five empirical criteria are used to predict swelling potential of soils using physical and index properties. The five criteria including Chen [45], modified Van der Merwe [46], Williams [47], Seed et al. [42], and AASHTO [48] were used to describe degrees of expansivity of the samples in both the boreholes (Table 8 and Fig. 7) and then the swelling descriptions were compared to descriptions based on MFSI. The obtained results are expressed in the following paragraphs.

The results obtained from the estimation of the swelling potential of the soil samples for the both boreholes are shown in Figs. 8 and 9. As can be seen from the Fig. 8, the Vander Merwe's criterion overestimates the soil expansivity in comparison with the other empirical criteria. According to Fig. 8, it can be concluded that among the five criteria, AASHTO [48] and Seed et al. [42] criteria have closer results to MFSI. In fact, other criteria don't show ignorable degree of swelling potential for the samples.
Table 6 Dispersivity class of the samples according to classification of Bell and Walker [38]

\begin{tabular}{|c|c|c|c|}
\hline Sample & Depth (m) & $\begin{array}{c}\text { Dispersivity } \\
\text { percentage (DP) }\end{array}$ & Classification \\
\hline \multirow{5}{*}{ Borehole A } & 1 & 40 & $\begin{array}{l}\text { Moderately } \\
\text { dispersive }\end{array}$ \\
\hline & 2 & 45.45 & $\begin{array}{l}\text { Moderately } \\
\text { dispersive }\end{array}$ \\
\hline & 3 & 40 & $\begin{array}{l}\text { Moderately } \\
\text { dispersive }\end{array}$ \\
\hline & 4 & 46.66 & $\begin{array}{l}\text { Moderately } \\
\text { dispersive }\end{array}$ \\
\hline & 5 & 43.75 & $\begin{array}{l}\text { Moderately } \\
\text { dispersive }\end{array}$ \\
\hline \multirow{6}{*}{ Borehole B } & 1 & 39.28 & $\begin{array}{l}\text { Moderately } \\
\text { dispersive }\end{array}$ \\
\hline & 2 & 43.33 & $\begin{array}{l}\text { Moderately } \\
\text { dispersive }\end{array}$ \\
\hline & 3 & 45 & $\begin{array}{l}\text { Moderately } \\
\text { dispersive }\end{array}$ \\
\hline & 4 & 33.33 & $\begin{array}{l}\text { Moderately } \\
\text { dispersive }\end{array}$ \\
\hline & 5 & 25.6 & $\begin{array}{c}\text { Slightly } \\
\text { dispersive }\end{array}$ \\
\hline & 6 & 11.76 & Non-dispersive \\
\hline
\end{tabular}

Table 7 Expansivity of the soil samples according to classification presented by Sridharan and Prakash [14]

\begin{tabular}{lccc}
\hline Sample & Depth $(\mathrm{m})$ & MFSI & Swelling potential \\
\hline \multirow{2}{*}{ Borehole } & 1 & 3 & Moderate \\
A & 2 & 2.8 & Moderate \\
& 3 & 2.6 & Moderate \\
& 4 & 2.58 & Moderate \\
& 5 & 2.25 & Ignorable \\
Borehole & 1 & 2.7 & Moderate \\
B & 2 & 2.55 & Moderate \\
& 4 & 2.50 & Moderate \\
& 5 & 2.26 & Ignorable \\
& 6 & 2.20 & Ignorable \\
\hline
\end{tabular}

It can be observed that the predictions based on the two methods of Chen and Williams match very well and similar condition is visible for the two criteria of AASHTO [48] and Seed et al. [42]. The obtained results for borehole B are also shown in Fig. 9. According to Fig. 9, it can be concluded that Van der Merwe criterion classify the soil samples in ignorable and moderate categories same as MFSI index. Although, criteria of Williams [47] and Seed et al. [42]. classify samples of borehole B into ignorable and moderate but with different percentages. 
Table 8 Classification of the soil samples from expansivity point of view according to classifications of Chen, Van Der Merwe and AASHTO.

\begin{tabular}{|c|c|c|c|c|}
\hline \multirow{3}{*}{ Chen classification [45] } & \multicolumn{4}{|c|}{ Expansivity degree } \\
\hline & \multirow[t]{2}{*}{ Low $(0<$ PI $<15)$} & Moderate $(15<\mathrm{PI}<35)$ & \multirow{2}{*}{$\begin{array}{c}\text { High }(35<\mathrm{PI}<55) \\
6 \mathrm{~B}\end{array}$} & \multirow[t]{2}{*}{ Very high $(\mathrm{PI}>55)$} \\
\hline & & $1 \mathrm{~A}, 2 \mathrm{~A}, 3 \mathrm{~A}, 4 \mathrm{~A}, 5 \mathrm{~A}, 1 \mathrm{~B}, 2 \mathrm{~B}, 3 \mathrm{~B}, 4 \mathrm{~B}, 5 \mathrm{~B}$ & & \\
\hline \multirow{3}{*}{$\begin{array}{l}\text { Van Der Merwe } \\
\text { classification [46] }\end{array}$} & \multicolumn{4}{|c|}{ Expansivity degree } \\
\hline & \multirow[t]{2}{*}{ Low $(0<$ PI < 12) } & Moderate $(12<\mathrm{PI}<24)$ & High $(24<$ PI < 32) & Very high $(\mathrm{PI}>32)$ \\
\hline & & $1 \mathrm{~A}, 2 \mathrm{~A}, 1 \mathrm{~B}, 3 \mathrm{~B}, 4 \mathrm{~B}$ & $3 \mathrm{~A}, 4 \mathrm{~A}, 2 \mathrm{~B}, 5 \mathrm{~B}$ & $5 \mathrm{~A}, 6 \mathrm{~B}$ \\
\hline \multirow{3}{*}{$\begin{array}{l}\text { AASHTO classification } \\
{[48]}\end{array}$} & \multicolumn{4}{|c|}{ Expansivity degree } \\
\hline & Low $(0<\mathrm{LL}<50$ and $0<\mathrm{PI}<25)$ & Moderate $(50<\mathrm{LL}<60$ and $25<\mathrm{PI}<35)$ & \multirow{2}{*}{\multicolumn{2}{|c|}{ High $(\mathrm{LL}>60$ and $\mathrm{PI}>35)$}} \\
\hline & $1 \mathrm{~A}, 2 \mathrm{~A}, 1 \mathrm{~B}, 3 \mathrm{~B}, 4 \mathrm{~B}$ & $3 \mathrm{~A}, 4 \mathrm{~A}, 5 \mathrm{~A}, 2 \mathrm{~B}, 5 \mathrm{~B}, 6 \mathrm{~B}$ & & \\
\hline
\end{tabular}
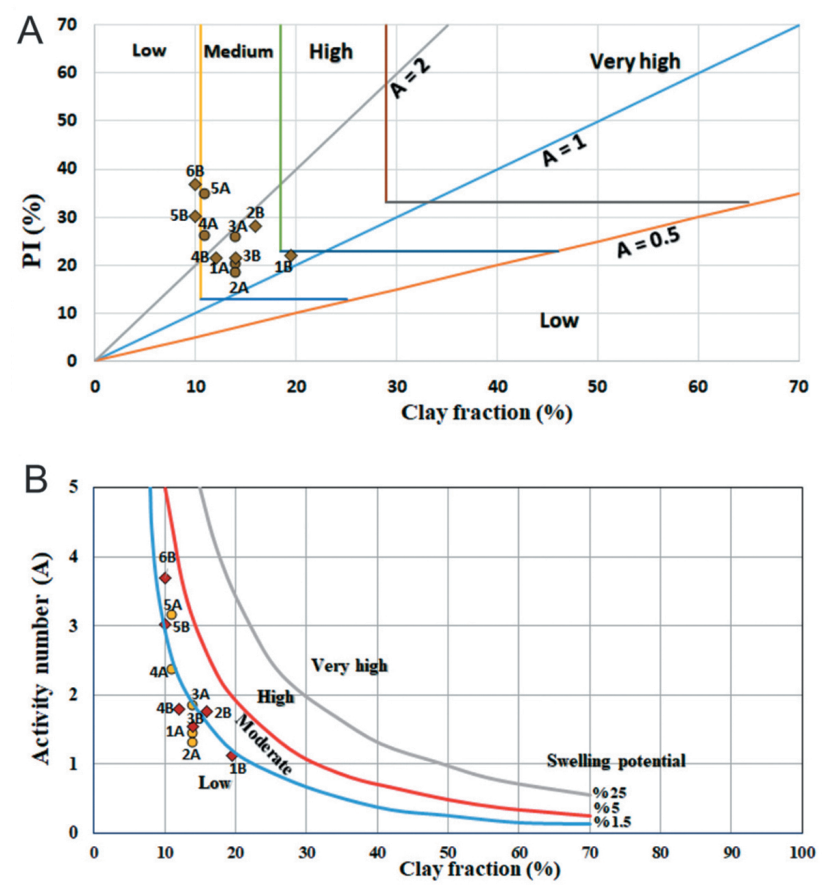

Fig. 7 Classification of the soil samples based on expansivity using classifications reported by (A) Williams et al. [47] and (B) Seed et al. [42]

\subsection{Relationship between the dispersivity and expansivity of the soil samples}

As it was mentioned in Section 1, one of the aims of this study is assessment of relationships between dispersivity and expansivity indices. Hence, in order to investigate the relationship between the measured dispersivity indices (SAR and dispersivity percentage) and the measured swelling indices (MFSI, activity number and plastic index), statistical regression models were used. Fig. 10 illustrates correlations among the dispersivity and the expansivity indices. While most of the correlations show severely scattered results, it was observed that SAR and MFSI are meaningfully correlated together. The coefficient of determination $\left(R^{2}\right)$ is 0.91 for the SAR vs. MFSI relation, whereas that is 0.34 for the DP vs. MFSI relation. This suggests that swelling might be controlled more predominantly by content of $\mathrm{Na}, \mathrm{Ca}$ and $\mathrm{Mg}$ cations which are considered in SAR parameter. Although, SAR is slightly correlated to PI and A with determination coefficients of 0.5 and 0.62 respectively. In spite of extend application of DP in description of dispersivity, this index is not meaningfully correlated
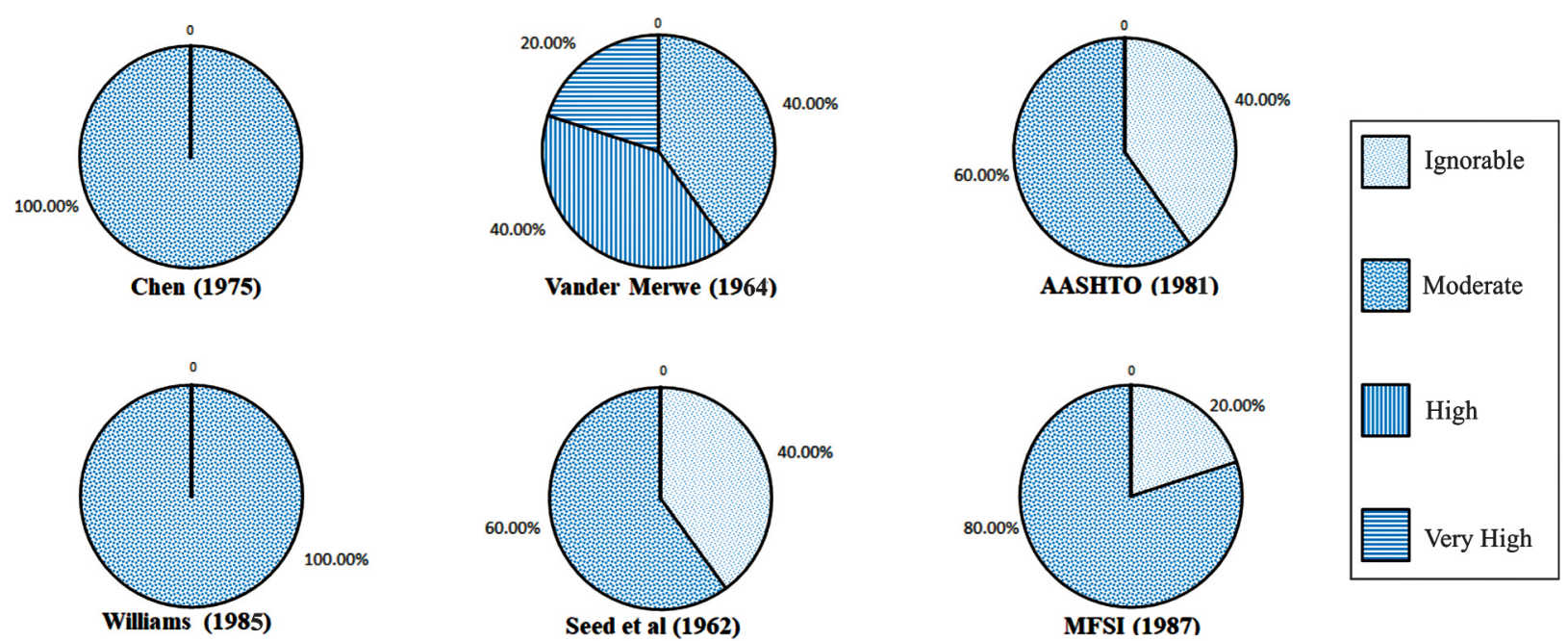

Fig. 8 The comparison of the swelling estimation of the indirect methods and the direct method in Borehole A 

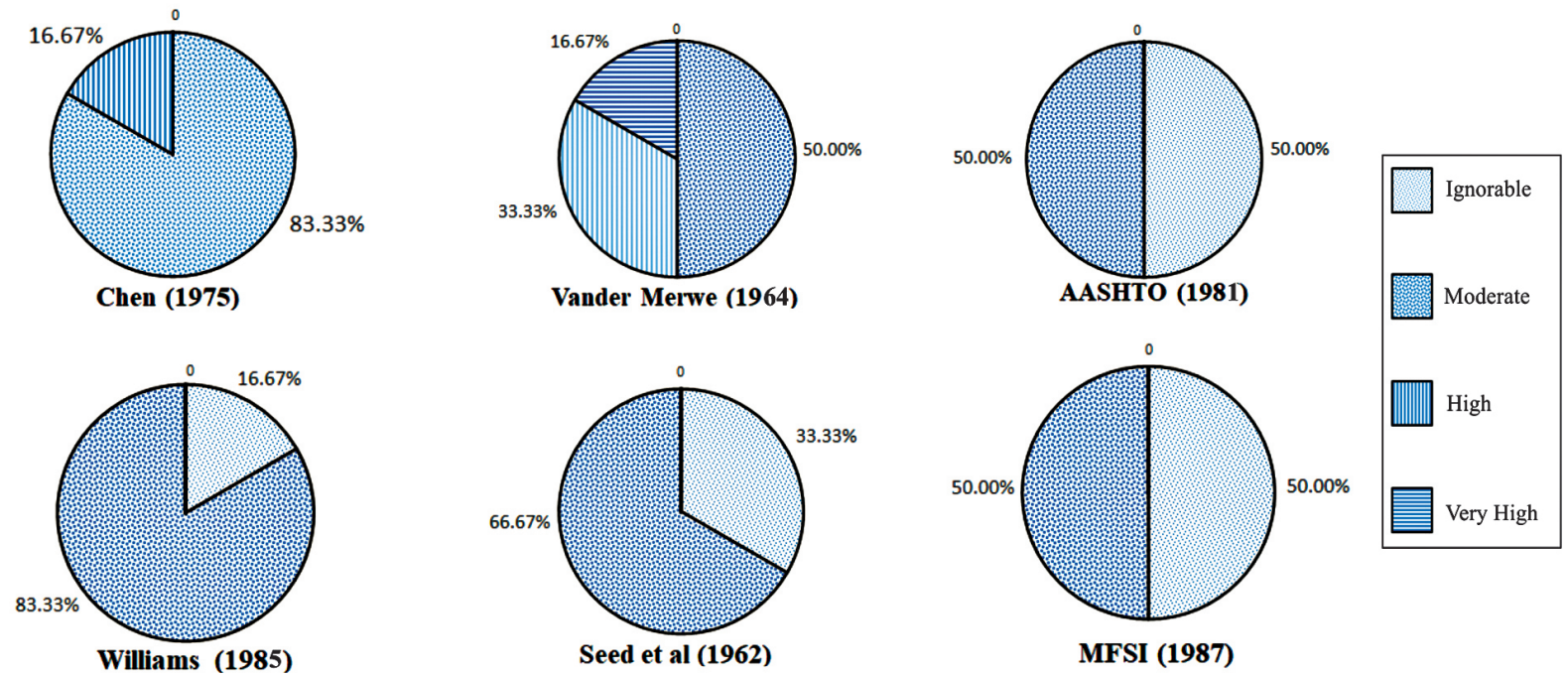

Fig. 9 Comparison of the swelling estimation of the indirect methods and the direct method in Borehole B
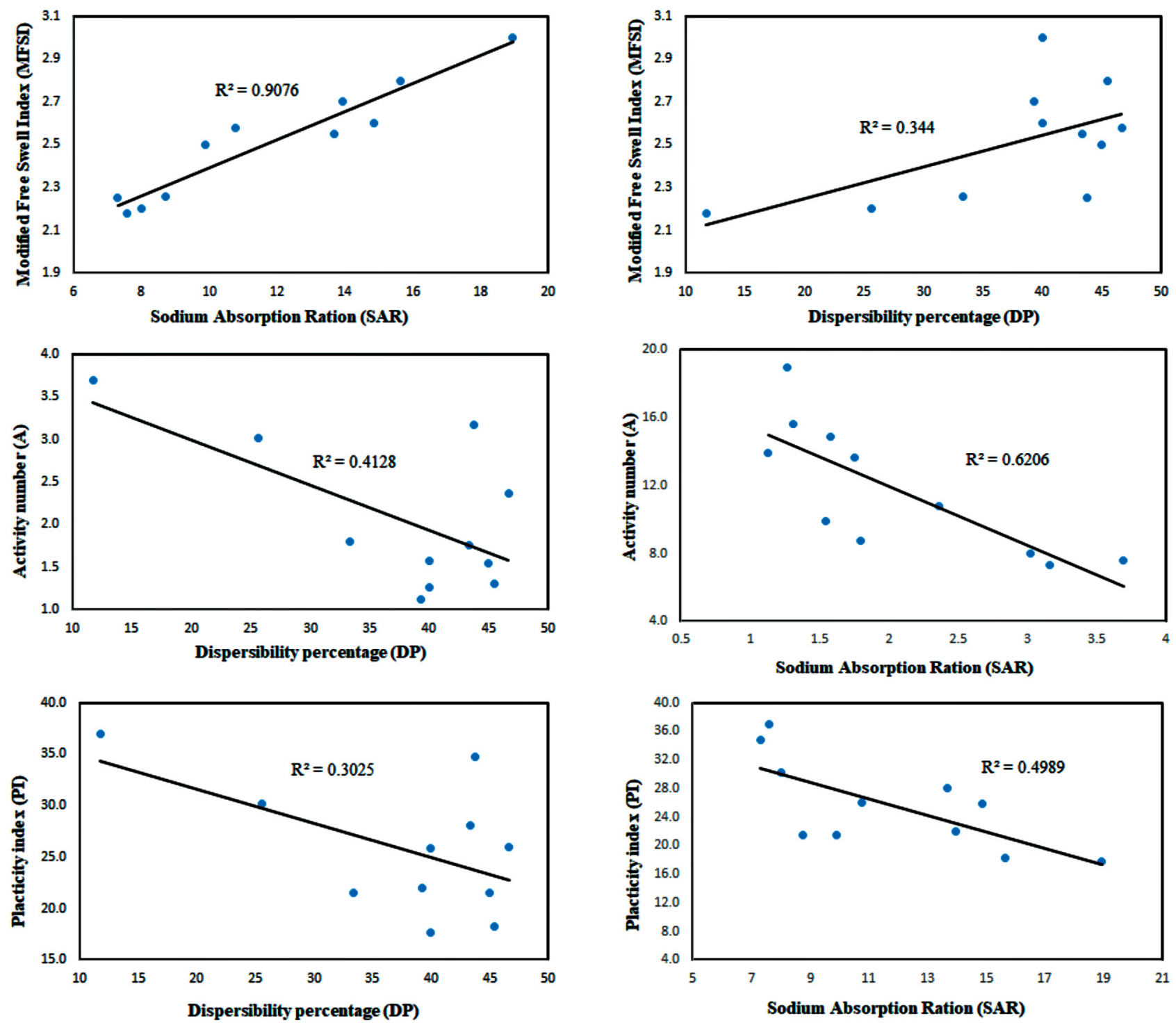

Fig. 10 Statistical Results of the relationships among indices of dispersivity and expancivity 
with the swelling indices (Fig. 10). To justify this subject, it can be say that DP is a physical parameter which is defined based on a physical test (the double hydrometer test) without considering chemical properties that are important in occurrence of swelling.

\section{Conclusions}

In this study, representative soil samples of two boreholes drilled in the southeast of Yazd-Ardakan plain, were examined to identify their dispersivity and expansivity. For this purpose, mineralogical and soil chemistry experiments were carried out to determine the soil composition. Also, the physical properties of the samples were studied. The results showed that the soil samples were classified in the categories of CL to $\mathrm{CH}$ based on the unified soil classification system (USCS). According to the XRD results, quartz, calcite, dolomite and clay minerals are the major constituents of the soil samples and plagioclase (albite) is the minor constituents. Moreover, calculation of percentages of clay minerals revealed that the main clay mineral is illite and the other clay minerals are kaolinite, chlorite and smectite. The results of the XRF test showed that, the percentage of $\mathrm{Na}_{2} \mathrm{O}$ for the borehole $\mathrm{A}$ is less than that for borehole $\mathrm{B}$, but the percentage of $\mathrm{CaO}$ is slightly higher. Therefore, it can be expected that the dispersivity potential in borehole A is less than borehole B.

The dispersivity degree of the soil samples were investigated using the chemical parameters, pinhole test and double hydrometer test. According to percentage of sodium (PS) criterion and Sherard's classification, which are defined based on chemical parameters, the soil samples were classified in moderately dispersive to dispersive categories. While pinhole and double hydrometer tests present

\section{References}

[1] Singh, B., Gahlot, P. K., Purohit, D. G. M. "Dispersive SoilsCharacterization, Problems and Remedies", International Research Journal of Engineering and Technology, 5(6), pp. 2478-2484, 2018.

[2] Maharaj, A. "The Evaulation of test protocols for dispersive soil identification in Southern Africa", $\mathrm{PhD}$ Thesis, University of Pretoria, 2013.

[3] Umesh, T. S., Dinesh, S. V., Sivapullaiah, P. V. "Characterization of Dispersive Soils", Materials Sciences and Applications, 2(6), pp. 629-633, 2011.

https://doi.org/10.4236/msa.2011.26085

[4] Djoković, K., Čaki, L., Šušić, N., Hadži-Niković, G. "Methods for assessment and identification of dispersive soils", In: XVI Danube - European Conference on Geotechnical Engineering, Skopje, Macedonia, 2018, pp. 205-210. https://doi.org/10.1002/cepa.672 lower degree of dispersivity for the samples (moderately dispersive to nondispersive) than the chemical parameters. Regardless of which of the indices is more success in description of real dispersivity degree, important point about the dispersivity of the soil samples is that in both the boreholes degree of dispersivity decrease with increasing depth. Also, the swelling potential of the soil samples were estimated using direct method (modified free swell index, MFSI) and indirect criteria (Chen, modified Van der Merwe [46], Williams [47], Seed et al. [42], and AASHTO [48]). The results showed that the soil samples have ignorable to moderate expansivity according to MFSI classification. Different dispersivity degrees predicted on the same samples based on the indirect criteria. Assessing the swelling degree descriptions, defined by the indirect criteria and MFSI values, revealed that AASHTO has the closest estimation to MFSI among the indirect criteria. Considering the different results obtained based on the different methods in describing dispersivity, it is suggested to perform a significant number of experiments and evaluate the results together to get more reliable dispersivity description. Totally it could be concluded that with increasing depth the percentage of fine grain in the soil samples decreases and consequently both dispersivity and expansivity are reduced in the boreholes. In another part of this study, based on the obtained results and statistical methods, the relationship between dispersivity and the expansivity was examined. SAR and DP were correlated with MFSI, A and PI. Except correlation between SAR and MFSI which was reliable with $R^{2}=0.91$, the rest correlations were weak and unreliable. Therefore, the assessments showed that SAR can be used as a reasonable index of soil swelling in addition to application in dispersivity description.

[5] Premkumar, S., Piratheepan, J., Arulrajah, A., Disfani, M. M., Rajeev, P. "Experimental Study on Contact Erosion Failure in Pavement Embankment with Dispersive Clay", Journal of Materials in Civil Engineering, 28(4), Article number: 04015179, 2015. https://doi.org/10.1061/(ASCE)MT.1943-5533.0001452

[6] Turgut, A., Isik, N. S., Kasapoglu, K. "Investigation of factors affecting the dispersibility of clays and estimation of dispersivity", Bulletin of Engineering Geology and the Environment, 76(3), pp. 1051-1073, 2017. https://doi.org/10.1007/s10064-016-0935-X

[7] Nagy, G., Nagy, L., Kopecskó, K. "Examination of the Physicochemical Composition of Dispersive Soils", Periodica Polytechnica Civil Engineering, 60(2), pp. 269-279, 2016. https://doi.org/10.3311/PPci.8896 
[8] Mahalder, B., Schwartz, J. S., Palomino, A. M., Zirkle, J. "Relationships between physical-geochemical soil properties and erodibility of streambanks among different physiographic provinces of Tennessee, USA", Earth Surface Processes and Landforms, 43(2), pp. 401-416, 2018.

https://doi.org/10.1002/esp.4252

[9] Masoodi, A., Majdzadeh Tabatabai, M. R., Noorzad, A., Samadi, A. "Effects of soil physico-chemical properties on stream bank erosion induced by seepage in northeastern Iran", Hydrological Sciences Journal, 62(16), pp. 2597-2613, 2017. https://doi.org/10.1080/02626667.2017.1403030

[10] Abbaslou, H., Hadifard, H., Poorgohardi, A. "Characterization of dispersive problematic soils and engineering improvement: A review", Computations and Materials in Civil Engineering, 1(2), pp. 65-83, 2016.

[11] Vakili, A. H., Selamat, M. R., Moayedi, H., Amani, H. "Stabilization of Dispersive Soils by Pozzolan", In: Dolhon, A. M., Drerup, M. J., Kardon, J. B., Hancock, D. S., Chen, S. (eds.) Forensic Engineering 2012: Gateway to a Safer Tomorrow, American Society of Civil Engineers, Reston, VA, USA, pp. 726-735, 2013. https://doi.org/10.1061/9780784412640.077

[12] Athukorala, R. "Geotechnical characteristics of an erodible stabilized by lingo sulfonate an analytical perspective", $\mathrm{PhD}$ Thesis, University of Wollongong, 2013.

[13] Batool, S. "Improvement of CBR and Compaction Characteristics of Bauxite Rich Dispersive Soils Available in Pakistan: A Case Study of Khushab Soil", Technical Journal (Taxila), 20(4), pp. 19-27, 2016.

[14] Sridharan, A., Prakash, K. "Classification procedures for expansive soils", Proceedings of the Institution of Civil EngineersGeotechnical Engineering, 143(4), pp. 235-240, 2000. https://doi.org/10.1680/geng.2000.143.4.235

[15] Holtz, R. D., Kovacs, W. D. "An introduction to geotechnical engineering", A Paramount Communications Company, Englewood Cliffs, NJ, USA, 1981.

[16] Forouzan, A. J. "Prediction of Swelling Behavior of Expansive Soils Using Modified Free Swell Index, Methylene Bue and Swell Oedometer Tests", MSc Thesis, Middle East Technical University, 2016.

[17] Attom, M. F., Barakat, S. "Investigation of three methods for evaluating swelling pressure of soils", Environmental and Engineering Geoscience, 6(3), pp. 293-299, 2000.

https://doi.org/10.2113/gseegeosci.6.3.293

[18] Muntohar, A. S. "Prediction and classification of swelling clay soil", In: Swelling soils recent advances in characterization and treatment, Taylor \& Francis Group, London, UK, 2006, pp. 25-36.

[19] Tosun, H., Türköz, M. "The use of methylene blue test for predicting swell parameters of natural clay soils", Scientific Research and Essays, 6(8), pp. 1780-1792, 2011.

[20] Mishra, A. K., Dhawan, S., Rao, S. M. "Analysis of Swelling and Shrinkage Behavior of Compacted Clays", Geotechnical and Geological Engineering, 26(3), pp. 289-298, 2008. https://doi.org/10.1007/s10706-007-9165-0

[21] Lin, B., Cerato, A. B. "Prediction of expansive soil swelling based on four micro-scale properties", Bulletin of Engineering Geology and the Environment, 71(1), pp. 71-78, 2012.

https://doi.org/10.1007/s10064-011-0410-7
[22] Liu, S., Chu, Y., Wang, F., Du, Y., Zha, F. "The expansibility prediction of expansive soil with electrical resistivity method", In: ICSMGE 2017 - 19th International Conference on Soil Mechanics and Geotechnical Engineering, Seoul, South Korea, 2017, pp. 1055-1058.

[23] Chittoori, B., Tamim, M. M., Gajurel, A., Mishra, D. "Evaluating the Ability of Swell Prediction Models to Predict the Swell Behavior of Excessively High Plastic Soils", In: 2nd PanAmerican Conference on Unsaturated Soils, Dallas, TX, USA, 2017, pp. 177-189. https://doi.org/10.1061/9780784481707.019

[24] Udukumburage, R. S., Gallage, C., Dawes, L. A. "Loaded swell tests to estimate the heave of the expansive soil in instrumented soil column", In: 8th International Conference on Geotechnique, Construction Materials and Environment, Kuala Lumpur, Malaysia, 2018, pp. 390-395.

[25] Mahmoudi, K. "Laboratory study of problematic soils in Ardakan city", MSc Thesis, Yazd University, 2010.

[26] Ekhtesasi, M. R., Sepehr, A. "Investigation of wind erosion process for estimation, prevention, and control of DSS in Yazd-Ardakan plain", Environmental Monitoring and Assessment, 159(1-4), pp. 267-280, 2008.

https://doi.org/10.1007/s10661-008-0628-4

[27] American Society for Testing and Materials "ASTM D221610 Standard Test Methods for Laboratory Determination of Water (Moisture) Content of Soil and Rock by Mass", ASTM International, West Conshohocken, PA, 2010.

https://doi.org/10.1520/D2216-10

[28] American Society for Testing and Materials "ASTM D118896(2002) Standard Test Method for Bulk Specific Gravity and Density of Compacted Bituminous Mixtures Using Paraffin-Coated Speciments", ASTM International, West Conshohocken, PA, 1996. https://doi.org/10.1520/D1188-96R02

[29] American Society for Testing and Materials "ASTM D854-14 Standard Test Methods for Specific Gravity of Soil Solids by Water Pycnometer", ASTM International, West Conshohocken, PA, 2014. https://doi.org/10.1520/D0854-14

[30] American Society for Testing and Materials "ASTM C117-17 Standard Test Method for Materials Finer than 75- $\mu \mathrm{m}$ (No. 200) Sieve in Mineral Aggregates by Washing", ASTM International, West Conshohocken, PA, 2017. https://doi.org/10.1520/C0117-17

[31] American Society for Testing and Materials "ASTM D4318-17e1 Standard Test Methods for Liquid Limit, Plastic Limit, and Plasticity Index of Soils", ASTM International, West Conshohocken, PA, 2017.

https://doi.org/10.1520/D4318-17E01

[32] Zhou, X., Liu, D., Bu, H., Deng, L., Liu, H., Yuan, P., Peixin, D., Song, H. "XRD-based quantitative analysis of clay minerals using reference intensity ratios, mineral intensity factors, Rietveld, and full pattern summation methods: A critical review", Solid Earth Sciences, 3(1), pp. 16-29, 2018. https://doi.org/10.1016/j.sesci.2017.12.002

[33] Mermut, A. R., Cano, A. F. "Baseline studies of the clay minerals society source clays: chemical analyses of major elements", Clays and Clay Minerals, 49(5), pp. 381-386, 2001. https://doi.org/10.1346/CCMN.2001.0490504 
[34] Maharaj, A., Paige-Green, P. "The Pinhole Test for Dispersive Soil Identification", Engineering Geology for Society and Territory, 5, pp. 1299-1303, 2015.

[35] Sherard, J. L., Steele, E. F., Decker, R. S., Dunnigan, L. P. "Pinhole test for identifying dispersive soils", Journal of the Geotechnical Engineering Division, 102(1), pp. 69-85, 1976.

[36] American Society for Testing and Materials "ASTM D4647 / D4647M-13 Standard Test Methods for Identification and Classification of Dispersive Clay Soils by the Pinhole Test", ASTM International, West Conshohocken, PA, 2013. https://doi.org/10.1520/D4647_D4647M-13

[37] American Society for Testing and Materials "ASTM D4221-18 Standard Test Method for Dispersive Characteristics of Clay Soil by Double Hydrometer", ASTM International, West Conshohocken, PA, 2018. https://doi.org/10.1520/D4221-18

[38] Bell, F. G., Walker, D. "A further examination of the nature of dispersive soils in Natal, South Africa", Quarterly Journal of Engineering Geology and Hydrogeology, 33(3), pp. 187-199, 2000. https://doi.org/10.1144/qjegh.33.3.187

[39] Sivapullaiah, P. V., Sitharam, T. G., Rao, K. S. "Modified Free Swell Index for Clays", Geotechnical Testing Journal, 10(2), pp. 80-85, 1987.

https://doi.org/10.1520/GTJ10936J

[40] Yilmaz, I. "Indirect estimation of the swelling percent and a new classification of soils depending on liquid limit and cation exchange capacity", Engineering geology, 85(3-4), pp. 295-301. https://doi.org/10.1016/j.enggeo.2006.02.005

[41] Israr, J. "Development of Correlations between Index Properties and Swelling Characteristics of Swelling Soils", MSc Thesis, University of Wollongong, NSW, Australia, 2012.

[42] Seed, H. B., Woodward, J. R., Lundgren, R. "Prediction of Swelling Potential for Compacted Clays", Journal of the Soil Mechanics and Foundations Division, 88(3), pp. 53-88, 1962.

https://doi.org/10.4236/jsemat.2015.52009
[43] Erzin, Y. "Correlations for quick prediction of swell pressures", Electronic Journal of Geotechnical Engineering, 9(1), 2004.

[44] Ranganatham, B., Satyanarayana, B. "A rational method of predicting swelling potential for compacted expansive clays", In: Proceedings of the 6th International Conference on Soils Mechanics and Foundation Engineering, University of Toronto Press, Toronto, Canada, 1965, pp. 92-96.

[45] Chen, F. H. "Foundations on expansive soils", Elsevier, New York, NY, USA, 1975.

[46] Van der Merwe, D. H. "The prediction of heave from the plasticity index and percentage clay fraction of soils", Civil Engineering = Siviele Ingenieurswese, 6(6), pp. 103-107, 1964.

[47] Williams, A. A. B., Pidgeon, J. T., Day, P. W. "Expansive soils", Civil Engineering $=$ Siviele Ingenieurswese, 27(7), pp. 367-377, 1985.

[48] American Association of State Highway and Transportation Officials "AASHTO T 258 Standard Method of Test for Determining Expansive Soils", AASHTO, USA, 1981.

[49] American Society for Testing and Materials "ASTM D248717 Standard Practice for Classification of Soils for Engineering Purposes (Unified Soil Classification System)", ASTM International, West Conshohocken, PA, 2017. https://doi.org/10.1520/D2487-17

[50] Das, B. M., Sobhan, K. "Principles of geotechnical engineering", Cengage Learning, Boston, USA, 2013.

[51] Sherard, J. L., Dunnigan, L. P., Decker, R. S. "Identification and Nature of Dispersive Soils", Journal of the Geotechnical Engineering Division, 102(4), pp. 287-301, 1976. 